\title{
De verplichting tot schadevergoeding wegens schending van financieel toezichtrecht in het licht van kapitaalbescherming en het gelijkheidsbeginsel
}

\author{
HvJ EU 19 december 2013, C-174/12, NJ 2014/184 m.nt. Mok, \\ Ondernemingsrecht 2014/71 m.nt. Arons (Hirmann/Immofinanz AG) \\ Mr.J.H.L.Beckers*
}

\begin{abstract}
Inleiding
Op 19 december 2013 heeft het Europese Hof van Justitie uitspraak gedaan in een prejudiciële procedure waarin verschillende vragen waren gesteld omtrent Europees vennootschaps- en effectenrecht. De zaak draaide om een claim van een belegger jegens een beursvennootschap wegens schending van een aantal effectenrechtelijk georiënteerde voorschriften, waaronder het verbod van marktmanipulatie. Naar Oostenrijks recht bestaat in dit soort gevallen een verplichting voor de vennootschap tot terugbetaling van de koopsom. De verwijzende rechter stelde verschillende vragen omtrent de uitleg van de eerste en tweede richtlijn vennootschapsrecht, de transparantierichtlijn, de prospectusrichtlijn en de richtlijn marktmisbruik. In het onderstaande bespreek ik eerst de casus en het oordeel van het Hof, om vervolgens enkele kanttekeningen bij deze uitspraak te plaatsen, onder meer vanuit het perspectief van het Nederlandse recht.
\end{abstract}

\section{Feiten}

Hirmann, een particulier, kocht op 7 januari 2005 voor ongeveer EUR 10.000 aandelen in Immofinanz AG (hierna: Immofinanz), een aan de Weense beurs genoteerde vennootschap opgericht naar Oostenrijks recht. De aankoop, waarbij een bank (Aviso Zeta AG) als makelaar optrad, vond plaats op de secundaire markt. De koopprijs werd door de koper betaald aan Aviso Zeta en de betrokken aandelen zijn geboekt op een

Mr. J.H.L. Beckers is wetenschappelijk medewerker bij NautaDutilh te Amsterdam en verbonden aan het Van der Heijden Instituut (Radboud Universiteit Nijmegen). effectenrekening op naam van Hirmann bij deze onderneming.

Hirmann verwijt Immofinanz dat zij onwettige maatregelen heeft genomen ter ondersteuning van haar aandelenkoers en dat het prospectus onvolledige, onjuiste of bedrieglijke informatie bevatte. In dit verband is tegen de voormalige leden van de raad van bestuur van Immofinanz strafvervolging ingesteld. Op het moment van de uitspraak waren verschillende daarmee verband houdende procedures aanhangig. Enigszins merkwaardig is de - inleidende? - opmerking van de advocaatgeneraal (hierna: A-G) dat de verwijzende rechter weliswaar nog geen feitelijke vaststellingen heeft gedaan betreffende de vraag of, en zo ja, in hoeverre Immofinanz misleidende informatie heeft verstrekt die Hirmann ertoe heeft gebracht aandelen te kopen, die hij anders misschien niet zou hebben gekocht, maar bepaalde feiten niet betwist worden (nr. 46); in deze procedure is dit immers irrelevant.

Tegen deze achtergrond vordert Hirmann bij wijze van schadevergoeding voor de verwijzende rechter de vernietiging van de overeenkomst betreffende de aandelenkoop. Daartoe heeft hij met name aangevoerd dat Immofinanz wordt veroordeeld tot terugbetaling van een bedrag dat overeenstemt met de oorspronkelijke koopprijs van de aandelen, vermeerderd met rente, in ruil waarvoor de aandelen worden teruggegeven aan deze vennootschap. Deze vordering vindt haar grondslag in de naar Oostenrijks recht geldende regeling die in het kader 
van de omzetting van de prospectus-, ${ }^{1}$ de transparantie- ${ }^{2}$ en de richtlijn marktmisbruik ${ }^{3}$ bepaalt dat (1) een vennootschap als uitgevende instelling aansprakelijk is jegens een verkrijger van aandelen van deze vennootschap wegens schending van in laatstgenoemde richtlijnen neergelegde informatieverplichtingen, en (2) de betrokken vennootschap wegens die aansprakelijkheid verplicht is aan de verkrijger een met de aankoopprijs van de aandelen overeenkomend bedrag terug te betalen en de aandelen terug te nemen.

Immofinanz betoogt onder meer dat genoemde vordering in strijd is met de dwingende beginselen van het nationale recht en van het gemeenschapsrecht betreffende de naamloze vennootschappen, met name wat het vereiste van instandhouding van het kapitaal van die vennootschappen betreft uit de tweede richtlijn. ${ }^{4}$ Aansprakelijkheid jegens Hirmann zou meebrengen dat één enkele aandeelhouder wordt beschermd ten koste van alle andere aandeelhouders en van haar schuldeisers.

\section{Het oordeel van het Hof van Justitie}

\section{Eerste en tweede vraag}

De Oostenrijkse rechter vroeg zich in de eerste plaats af of de nationale regeling op grond waarvan de vennootschap aansprakelijk is en een vordering tot terugbetaling bestaat jegens de benadeelde aandeelhouders verenigbaar is met artikel 12, $15,16,18,19$ (kapitaalbescherming) en 42 (gelijkheidsbeginsel) van de tweede richtlijn.

Het antwoord van het Hof valt uiteen in een aantal onderdelen.

Bij zijn antwoord stelt het Hof voorop dat zowel uit de bewoordingen als uit het doel van deze richtlijnbepalingen volgt dat zij slechts de rechtsbetrekkingen regelen die tussen

1. Richtlijn 2003/71/EG betreffende het prospectus dat gepubliceerd moet worden wanneer effecten aan het publiek worden aangeboden of tot de handel worden toegelaten (PbEG 2003, L 345/64), zoals gewijzigd bij Richtlijn 2010/73/EU van het Europees Parlement en de Raad van 24 november 2010 (PbEU 2010, L 327/1).

2. Richtlijn 2004/109/EG van het Europees Parlement en de Raad betreffende de transparantievereisten die gelden voor informatie over uitgevende instellingen waarvan effecten tot de handel op een gereglementeerde markt zijn toegelaten (PbEG 2004, L 390/38), zoals gewijzigd bij Richtlijn 2010/73/EU van het Europees Parlement en de Raad van 24 november 2010 (PbEU 2010, L 327/1). Begin dit jaar is het Commissievoorstel tot wijziging van deze richtlijn aangenomen, zie $\operatorname{COM}(2013) 207$ def.

3. Richtlijn 2003/6/EG van het Europees Parlement en de Raad van 28 januari 2003 betreffende handel met voorwetenschap en marktmanipulatie (marktmisbruik) (PbEG 2003, L 96/16), zoals recentelijk gewijzigd bij Richtlijn 2014/57/EU van het Europees Parlement en de Raad van 16 april 2014 (PbEU 2014, L 173/79).

4. Richtlijn 77/91/EEG van de Raad van 13 december 1976 strekkende tot het coördineren van de waarborgen welke in de lidstaten worden verlangd van de vennootschappen om de belangen te beschermen zowel van de deelnemers in deze vennootschappen als van derden met betrekking tot de oprichting van de naamloze vennootschap, alsook de instandhouding en wijziging van haar kapitaal, zulks teneinde die waarborgen gelijkwaardig te maken (PbEG 1977, L 26, p. 1), zoals gewijzigd bij Richtlijn 92/101/EEG van de Raad van 23 november 1992 (PbEG 1992, L 347, p. 64). de vennootschap en haar aandeelhouders bestaan en uitsluitend voor zover die uit de vennootschapsovereenkomst voortvloeien en (derhalve) uitsluitend gelden voor de interne betrekkingen van de betrokken vennootschap. Dit maakt volgens het Hof dat de betrokken bepalingen van de tweede richtlijn zich niet verzetten tegen de Oostenrijkse regeling, omdat hier de aansprakelijkheid van Immofinanz jegens beleggers, wegens onregelmatigheden die door deze vennootschap zijn begaan vóór of op het tijdstip van de verkrijging van aandelen in die vennootschap, immers niet voortkomt uit de vennootschapsovereenkomst en zij niet louter de interne betrekkingen betreft van die vennootschap. In een dergelijk geval is sprake van een aansprakelijkheid die haar oorsprong vindt in de overeenkomst voor de koop van aandelen.

Met betrekking tot het gelijkheidsbeginsel van artikel 42 van de tweede richtlijn merkt het Hof op dat de aandeelhouders die schade hebben geleden doordat de vennootschap vóór of op het tijdstip van de verkrijging van haar aandelen een fout heeft begaan, zich niet in een identieke situatie bevinden als die van de aandeelhouders van dezelfde vennootschap van wie de rechtspositie niet nadelig is beïnvloed door die fout.

Volgens het Hof is dat (niet geheel duidelijk is waar 'dat' naar verwijst, zie het commentaar hierna) juist de reden waarom in artikel 20 lid 1 onder $\mathrm{d}$ van de tweede richtlijn aan lidstaten de mogelijkheid wordt geboden om de verkrijging van eigen aandelen op grond van een wettelijke verplichting uit te zonderen van de beperkingen die de richtlijn daaraan stelt, en kan een dergelijke verkrijging niet worden geacht ertoe te strekken het kapitaal van de vennootschap te verminderen of de aandelenkoers ervan kunstmatig te verhogen.

Ook is volgens het Hof geen sprake van een uitkering in de zin van artikel 15 van de tweede richtlijn bij een betaling door een vennootschap aan een aandeelhouder wegens onregelmatigheden die deze vennootschap vóór of op het tijdstip van de verkrijging van haar aandelen heeft begaan.

Het terugnemen van aandelen in dit soort omstandigheden valt ook niet binnen de werkingssfeer van artikel 18 van de tweede richtlijn, dat regels bevat voor het nemen van eigen aandelen, omdat naar het oordeel van het Hof een dergelijke verkrijging voortvloeit uit de wettelijke verplichting op grond waarvan die vennootschap de gelaedeerde investeerder dient te vergoeden, en een dergelijke verplichting '(...) helemaal niet [past] in de ratio legis van dat artikel'.

De vraag of Oostenrijk ervoor mocht kiezen aansprakelijkheid op de vennootschap zelf te leggen, beantwoordt het Hof bevestigend. Dat de vennootschap in haar hoedanigheid van effectenuitgevende instelling naar Oostenrijks recht zelf aansprakelijk kan zijn jegens beleggers, voldoet volgens het Hof aan de voorwaarden van artikel 6 lid 1 van de prospectusrichtlijn en artikel 7 van de transparantierichtlijn, zonder dat het in artikel 17 lid 1 van laatstgenoemde richtlijn neergelegde begin- 


\section{Vennootschap Onderneming}

sel van gelijke behandeling in het gedrang komt. Het Hof wijst voorts op artikel 25 lid 1 van de prospectusrichtlijn, artikel 28 lid 1 van de transparantierichtlijn en artikel 14 lid 1 van de richtlijn marktmisbruik, waar in vergelijkbare bewoordingen tot uitdrukking wordt gebracht dat de lidstaten, onverminderd hun recht om strafrechtelijke sancties op te leggen, er zorg voor dienen te dragen dat overeenkomstig hun nationale wetgeving passende administratieve maatregelen of administratieve sancties kunnen worden opgelegd aan de verantwoordelijke personen, indien de ter uitvoering van deze richtlijnen vastgestelde bepalingen niet zijn nageleefd, waarbij deze maatregelen doeltreffend, evenredig en afschrikkend dienen te zijn, dit 'onverminderd hun wettelijke aansprakelijkheidsregeling'. Hoewel in geen van de bedoelde bepalingen met zoveel woorden wordt verwezen naar het aansprakelijkheidsrecht van de lidstaten, neemt dat niet weg dat het Hof met betrekking tot de toekenning van een schadevergoeding en een eventuele mogelijkheid om punitieve schadevergoeding toe te kennen, reeds heeft geoordeeld dat, bij gebreke van Unierechtelijke bepalingen ter zake, de interne rechtsorde van elke lidstaat de criteria voor de vaststelling van de omvang van de schadevergoeding dient te bepalen, mits het gelijkwaardigheidsbeginsel en het doeltreffendheidsbeginsel in acht worden genomen. ${ }^{5}$ De conclusie van het Hof is dat de lidstaten bij de keuze van de sancties die worden toegepast bij schending door de uitgevende vennootschappen van de uit die richtlijnen voortvloeiende verplichtingen, over een ruime beoordelingsmarge beschikken, mits het Unierecht in acht wordt genomen, en dat hieruit tevens volgt dat wanneer een instelling die aandelen uitgeeft aansprakelijk is, het aan de lidstaten is om de civielrechtelijke maatregel te kiezen waarmee de schade wordt vergoed. In casu biedt de wettelijke aansprakelijkheidsregeling waarin is voorzien bij de in geding zijnde nationale regeling, passend rechtsherstel voor de door de investeerder geleden schade en voor de schending van de informatieverplichting van die uitgevende instelling. Bovendien kan zij de uitgevende instellingen ervan weerhouden om investeerders te misleiden.

\section{Derde vraag}

De nationale rechter had ook gevraagd of de hiervoor genoemde bepalingen uit de tweede richtlijn zich verzetten tegen het nationale voorschrift dat de vennootschap in de nakoming van haar verplichting tot terugbetaling ook een beroep moet kunnen doen op het gebonden vermogen van de vennootschap en dat deze verplichting ook kan leiden tot haar insolventie.

Het Hof serveert deze vraag af als betrekking hebbend op een louter hypothetische situatie, aangezien de verwijzende rechter in zijn verzoek om een prejudiciële beslissing niet heeft uiteengezet hoe het antwoord op die vraag nuttig zou kunnen zijn voor de beslechting van het hoofdgeding en zich ertoe heeft beperkt in algemene bewoordingen te verwijzen naar het

5. Het Hof verwijst daarbij 'naar analogie' naar de arresten van 13 juli 2006, C-295/04-C-298/04, Jur. 2006, p. I-6619, punt 92 (Manfredi e.a.) en 6 juni 2013, C-536/11, n.n.g., punt 25-27 (Donau Chemie e.a.). gevaar dat de uitgevende vennootschap insolvent zou kunnen worden.

\section{Vierde vraag}

Ten vierde vroeg de nationale rechter zich af of artikel 12 en 13 van de eerste richtlijn, ${ }^{6}$ waarin respectievelijk de limitatieve gronden voor nietigheid van vennootschappen worden genoemd, alsmede de gevolgen van die nietigheid, aldus moeten worden uitgelegd dat zij in de weg staan aan een nationale regeling die in omstandigheden als die van het hoofdgeding voorziet in vernietiging met terugwerkende kracht van de overeenkomst tot koop van aandelen.

Het Hof antwoordt dat dat niet het geval is. Hiermee reageert hij op het betoog van Immofinanz dat wanneer zou worden toegestaan dat een investeerder de oorspronkelijk betaalde koopprijs zou terugvorderen, dit dezelfde gevolgen zou kunnen hebben als de vaststelling van de nietigheid van de vennootschap. ${ }^{7}$ Aan terugwerkende kracht staat ook niet in de weg het zogeheten E Friz-arrest, ${ }^{8}$ omdat dit arrest over een onvergelijkbaar geval ging. Zie voorts de conclusie van de A-G (nr. 95):

'Dat arrest mag niet in die zin worden opgevat dat het eist dat de lidstaten, in de context van de verschillende in casu aan de orde zijnde richtlijnen, ervoor zorgen dat de vernietiging van een aandelentransactie wegens schending door een vennootschap van haar informatieverplichting slechts ex nunc gevolgen sorteert.' 9

\section{Vijfde vraag}

Ten slotte rees nog de vraag of de reeds genoemde bepalingen uit de eerste en tweede richtlijn aldus moeten worden uitgelegd dat de litigieuze aansprakelijkheid naar Oostenrijks recht beperkt is tot de waarde van de aandelen op het tijdstip waarop de aanspraak te gelde wordt gemaakt, welke waarde in geval van een genoteerde vennootschap op basis van de beurskoers ervan wordt berekend.

Het Hof antwoordt - in essentie - dat dat niet het geval is. Het is aan de lidstaten om te kiezen voor een wettelijke aansprakelijkheidsregeling die voorziet in de terugbetaling aan de verkrijger van een bedrag dat overeenkomt met de koopprijs van de aandelen, vermeerderd met rente, dan wel voor een regeling die deze aansprakelijkheid beperkt tot de betaling van

6. Richtlijn 2009/101/EG van het Europees Parlement en de Raad van 16 september 2009 strekkende tot het coördineren van de waarborgen, welke in de lidstaten worden verlangd van de vennootschappen om de belangen te beschermen zowel van de deelnemers in deze vennootschappen als van derden, zulks teneinde die waarborgen gelijkwaardig te maken (PbEG 2009, L 258/11). In deze richtlijn worden alle wijzigingen in de oorspronkelijke eerste richtlijn (68/151/EEG) gecodificeerd.

7. Zoals blijkt uit de conclusie van de A-G, nr. 90.

8. HvJ EG 15 april 2010, C-215/08, Jur. 2010, p. I-2947 (E. Friz). Heel in het kort ging het om de herroeping van de overeenkomst tot toetreding tot een vastgoedfonds door een consument.

9. Cursivering in origineel. 
de prijs van de aandelen op het tijdstip waarop de schadevordering geldend wordt gemaakt.

\section{Kanttekeningen}

Deze uitspraak is naar de uitkomst beschouwd niet wereldschokkend. Het beroep van Immofinanz op het kapitaalbeschermingsrecht was even creatief als kansloos. Toch zijn er diverse takeaways, ook voor het Nederlandse recht.

\section{Kapitaalbescherming}

In de eerste plaats het oordeel dat het kapitaalbeschermingsrecht, zoals dat is overgenomen uit de tweede richtlijn, zich niet verzet tegen een verplichting tot terugbetaling als de onderhavige.

Volgens het Hof is van een ongeoorloofd verkrijgen van aandelen geen sprake, gelet op artikel 20 lid 1 onder $\mathrm{d}$ van de tweede richtlijn, waar het verkrijgen van aandelen krachtens een wettelijke verplichting is uitgezonderd van de regels die de richtlijn stelt aan de verkrijging van eigen aandelen. Opmerking verdient dat vanwege de vraagstelling hier geen rol speelde of Oostenrijk die mogelijkheid daadwerkelijk had toegepast. In een procedure voor de nationale rechter kan dat uiteraard niet buiten beschouwing blijven. Heeft een lidstaat geen gebruik gemaakt van de uitzonderingsmogelijkheid van artikel 20 lid 1 onder d, dan kan een partij zich daarop niet beroepen (voor zover aan een richtlijn al directe werking toekomt). De op grond van het Europese recht geldende verplichting tot richtlijnconforme interpretatie strekt zich niet uit tot dit soort facultatieve regels. ${ }^{10}$ Voor de goede orde: Nederland heeft ook geen gebruik gemaakt van deze uitzonderingsmogelijkheid.

Het Hof oordeelt verder dat ook artikel 18 van de tweede richtlijn, dat gaat over het nemen van aandelen, zich niet verzet tegen de Oostenrijkse regeling. Men kan zich evenwel afvragen of het met terugwerkende kracht nemen van aandelen of 'terugnemen', zoals het Hof het noemt, wel onder die regeling valt.

Het oordeel dat de Oostenrijkse verplichting tot terugbetaling ook niet aan te merken is als een uitkering in de zin van artikel 15 van de tweede richtlijn is alleszins begrijpelijk, maar wel opmerkelijk mager gemotiveerd. Dat dit zo eenvoudig nog niet is, volgt ook uit de overwegingen ter zake van de A-G. ${ }^{11}$ In de kern komen die erop neer dat er geen sprake is van een uitkering, omdat de terugbetaling van de koopsom (1) niet aan de aandeelhouder in die hoedanigheid wordt betaald, (2) aan de benadeelde aandeelhouder verschuldigd was, (3) niet op initiatief van de vennootschap geschiedde en (4) niet voortvloeide uit de vennootschapsrechtelijke betrek-

10. Zie HvJ EU 21 oktober 2010, C-227/09, Jur. 2010, p. I-10273 (Accardo).

11. Zie nr. 70 e.v. king. ${ }^{12}$ Het oordeel dat er geen sprake is van een uitkering lijkt mij trouwens evengoed van belang voor de betaling van een schadevergoeding (in geld) aan gedupeerde beleggers, hetgeen in Nederland de sanctie is op schending van financieel toezichtrecht (zie hierna).

\section{Gelijkheidsbeginsel}

Immofinanz had ook een beroep gedaan op het gelijkheidsbeginsel voor de Oostenrijkse rechter. Het Hof maakt daar korte metten mee. In de eerste plaats is het gelijkheidsbeginsel beperkt tot rechtsbetrekkingen die tussen de vennootschap en haar aandeelhouders bestaan en uitsluitend uit de vennootschapsovereenkomst voortvloeien, en geldt het uitsluitend voor de interne betrekkingen van de betrokken vennootschap (overweging 27). ${ }^{13}$ Voorts oordeelt het Hof dat aandeelhouders die schade hebben geleden doordat de vennootschap vóór of op het tijdstip van de verkrijging van haar aandelen een fout heeft begaan, zich niet in een identieke situatie bevinden als die van de aandeelhouders van dezelfde vennootschap van wie de rechtspositie niet nadelig is beïnvloed door die fout (overweging 30). Wat er verder zij van het eerste argument, het tweede leidt ertoe dat het gelijkheidsbeginsel een wel heel 'situationeel' karakter krijgt; welke aandeelhouder bevindt zich in deze benadering nog in gelijke omstandigheden ${ }^{14} \mathrm{Op}$ zichzelf past deze benadering goed bij de uit het Verenigde Bootlieden-arrest ${ }^{15}$ af te leiden regel dat een omstandigheid die de aandeelhouders uitsluitend persoonlijk raakt, niet in aanmerking wordt genomen. ${ }^{16}$ Maar of zich dit in de praktijk goed laat toepassen, is twijfelachtig. Zo kan men zich bijvoorbeeld afvragen hoe dit uitwerkt indien men zou aannemen - zoals de A-G en de Europese Commissie doen - dat de nationale rechter gehouden is alle aandeelhouders die aandelen hebben gekocht op basis van dezelfde misleidende informatie gelijk te behandelen. ${ }^{17}$

Ten slotte, na de overweging dat de aandeelhouders die schade hebben geleden doordat de vennootschap vóór of op het tijdstip van de verkrijging van haar aandelen een fout heeft begaan, zich niet in een identieke situatie bevinden als die van de aandeelhouders van dezelfde vennootschap van wie de rechtspositie niet nadelig is beïnvloed door die fout, oordeelt het Hof dat 'dat' juist de reden is waarom artikel 20 lid 1 onder $\mathrm{d}$ van de tweede richtlijn het een vennootschap moge-

12. Zie over de vraag wat als een uitkering moet worden gezien in het algemeen B. Bier, Uitkeringen aan aandeelhouders (Uitgave vanwege het Instituut voor Ondernemingsrecht, deel 42), Deventer: Kluwer 2003, p. 271-280.

13. Overweging 27. Zie uitgebreider over de betekenis hiervan het commentaar van Arons in Ondernemingsrecht.

14. Vgl. G.T.J. Hoff, Openbaarmaking van koersgevoelige informatie (Serie vanwege het Van der Heijden Instituut, deel 107), Deventer: Kluwer 2011, p. 587.

15. HR 31 december 1993, NJ 1994/436 m.nt. Maeijer.

16. Zie aldus C. Honée, Investor Relations, in: H. Beckman e.a., De nieuwe macht van de kapitaalverschaffer (Uitgave vanwege het Instituut voor Ondernemingsrecht, deel 57), Deventer: Kluwer 2007, p. 23. Zie ook Hoff 2011, p. 587-588.

17. Zie conclusie A-G, nr. 96, waar de Commissie instemmend geciteerd wordt. 


\section{Vennootschap Onderneming}

lijk maakt haar eigen aandelen te verkrijgen op grond van met name een wettelijke verplichting. Onduidelijk is waar het Hof dit op baseert. Vervolgens overweegt het Hof: 'Een dergelijke verkrijging [op grond van een wettelijke verplichting dus; JB] kan niet worden geacht er toe te strekken het kapitaal van de vennootschap te verminderen of de aandelenkoers ervan kunstmatig te verhogen.' Het eerste lijkt mij voor betwisting vatbaar; het laatste kan ik moeilijk plaatsen omdat de tweede richtlijn niet strekt tot bescherming tegen dit risico.

\section{'Private enforcement' van financieel recht}

Onduidelijk is of uit deze uitspraak kan worden afgeleid dat de lidstaten niet verplicht zouden zijn om de beschermingsbepalingen uit de prospectusrichtlijn, de transparantierichtlijn en de richtlijn marktmisbruik te sanctioneren met civielrechtelijke aansprakelijkheid (private enforcement), zoals wel in reactie op deze uitspraak is betoogd. ${ }^{18} \mathrm{Ik}$ aarzel op dit punt. Er is weliswaar een precedent, ${ }^{19}$ maar dat betrof een ander geval (aansprakelijkheid onder MiFID). Verder volgt uit onderhavige uitspraak niet ondubbelzinnig dat lidstaten niet gehouden zouden zijn tot het opleggen van civielrechtelijke sancties. Eerder valt hieruit op te maken dat de lidstaten juist wel daartoe gehouden zijn. Het Hof overweegt immers dat bij gebreke van Unierechtelijke bepalingen op dit punt de interne rechtsorde van elke lidstaat 'de criteria voor de vaststelling van de omvang van de schadevergoeding' dient te bepalen, mits het gelijkwaardigheidsbeginsel en het doeltreffendheidsbeginsel in acht worden genomen. Dat lijkt te impliceren dat een dergelijke schadevergoeding steeds tot de mogelijkheden moet behoren. Daarvoor pleit ook dat het Hof hier - naar analogie - verwijst naar zijn uitspraken die de basis vormen voor private enforcement in het mededingingsrecht. In deze en andere uitspraken ${ }^{20}$ oordeelde het Hof dat 'aan het nuttig effect van artikel 81 lid 1 EG zou worden afgedaan als in de nationale rechtsorde geen schadevergoeding gevorderd zou kunnen worden voor inbreuken op het communautaire mededingingsrecht (...)'.

Een kwestie die hiermee verwantschap vertoont, is of voornoemde richtlijnen nopen tot aansprakelijkheid van de vennootschap zelf. In de recent vernieuwde richtlijn marktmisbruik $^{21}$ wordt aansprakelijkheid voor de rechtspersoon inzake namens hem gepleegde strafbare handelingen expliciet voorgeschreven (art. 8). Voor de andere richtlijnen is dat minder duidelijk. Mogelijk kan dit worden opgemaakt uit artikel 6 van de prospectusrichtlijn en artikel 7 van de transparantierichtlijn, op grond waarvan de lidstaten ervoor zorg dienen te dragen dat de verantwoordelijkheid voor de in een prospectus opgenomen informatie respectievelijk voor de overeenkomstig die

18. Aldus Arons in zijn Ondernemingsrecht-commentaar bij deze uitspraak.

19. HvJ EU 30 mei 2013, C-604/11, JOR 2013/274 m.nt. D. Busch (Genil 48 SL e.a./Bankinter SA e.a.).

20. Zie ook HvJ EG 20 september 2001, C-453/99, Jur. 2001, p. I-6297 (Courage en Crehan), punt 26.

21. Richtlijn 2014/57/EU van het Europees Parlement en de Raad van 16 april 2014 betreffende strafrechtelijke sancties voor marktmisbruik (richtlijn marktmisbruik) (PbEU 2014, L 173/79). richtlijn op te stellen en openbaar te maken informatie ten minste bij de uitgevende instelling berust. Aldus ook expliciet de conclusie van de A-G, nr. 53:

'Artikel 6, lid 1, van de prospectusrichtlijn bepaalt dat de lidstaten er zorg voor te dienen dragen dat de verantwoordelijkheid voor de in een prospectus verstrekte informatie ten minste berust bij onder meer de uitgevende instelling. Bijgevolg druist een nationale regel volgens welke een naamloze vennootschap als uitgevende instelling jegens een investeerder aansprakelijk is wegens schending van de informatieverplichtingen, helemaal niet in tegen die bepaling, maar voldoet zij integendeel eraan. Het is juist dat artikel 6, lid 1, het mogelijk maakt "al naargelang van het geval" andere entiteiten dan de uitgevende instelling aansprakelijk te stellen voor schendingen van de informatieverplichtingen. Niets in de gegevens waarover het Hof beschikt, [wijst echter erop] dat in de onderhavige zaak een andere entiteit dan Immofinanz, in haar hoedanigheid van uitgevende instelling, verantwoordelijk was voor de informatie in haar prospectus. In omstandigheden waarin de uitgevende instelling verantwoordelijk is voor de verstrekte informatie vereist artikel 6 duidelijk dat de uitgevende instelling aansprakelijk wordt gesteld indien die informatie onjuist of misleidend is.'

In Nederland lijkt weinig twijfel mogelijk dat ook steeds de uitgevende instelling zelf aansprakelijk is bij schending van financiële toezichtwetgeving, mits die voor haarzelf verplichtingen behelst. Voor wat betreft de prospectusplicht, waar artikel 6 van de prospectusrichtlijn aansprakelijkheid van de uitgevende rechtspersoon dwingend voorschrijft (zie eerder), volgt dat uit de opzet van artikel 6:194 e.v. van het Burgerlijk Wetboek. ${ }^{22}$ Ook bij andere, soortgelijke verplichtingen is dat het geval. Een bekend voorbeeld is Fortis, dat onder meer wegens schending van de verplichting tot openbaarmaking van koersgevoelige informatie naast zijn oud-bestuurders aansprakelijk was. $^{23}$

\section{Omvang aansprakelijkheid}

De omvang van de aansprakelijkheid wordt volgens het Hof niet door de eerste en tweede richtlijn beperkt tot de beurskoers zoals die luidt op het moment waarop de aanspraak tot schadevergoeding geldend wordt gemaakt. Annotator Mok verwoordt het aldus, dat een aanspraak op schadeloosstelling

22. Zie daarover o.m. T.M.C. Arons, Cross-border enforcement of listed companies' duties to inform (Uitgave vanwege het Instituut voor Ondernemingsrecht, deel 87), Deventer: Kluwer 2012, p. 47-93, M.A. Blom, Prospectusaansprakelijkheid van de lead manager (Serie vanwege het Van der Heijden Instituut, deel 53), Deventer: Kluwer 1996, p. 66 e.v. en W.J.M. van Andel \& K. Rutten, Vorderingen van aandeelhouders op de vennootschap wegens een misleidende voorstelling van zaken in de financiële verslaggeving, TvI 2008, p. 225-234.

23. Rb. Midden-Nederland 15 februari 2012, JOR 2012/140 m.nt. Willems (Kortekaas c.s./Fortis NV/SA c.s.). Tegen deze uitspraak loopt overigens hoger beroep. 
volgens het nationale recht niet zonder meer verloren gaat doordat de harmonisatie daarin niet voorziet.

Het oordeel van het Hof sluit aan bij zijn vaste rechtspraak dat het oordeel over de wijze van berekening van de schadevergoeding aan de nationale rechter is. ${ }^{24}$ Meestal wordt deze rechtspraak geciteerd onder vermelding van het feit dat dit niet wegneemt dat het Unierecht daarbij gerespecteerd moet worden. Onduidelijk is waarom dat in dit geval niet gebeurd is. In overweging 44 wordt wel geoordeeld dat een aansprakelijkheidsregeling als de Oostenrijkse binnen de aan de lidstaten verleende beoordelingsmarge valt en niet in strijd is met het Unierecht, maar die beoordeling zag niet - althans niet specifiek - op het element van de berekening van de schadevergoeding. Ik zou denken dat de berekening van de schadevergoeding in ieder geval geen afbreuk mag doen aan de doeltreffendheid en dergelijke van de desbetreffende regels. Zo is aannemelijk dat een nationale regeling die aansluit bij de beurskoers over een periode waarin de aandelen zijn gedaald, juist als gevolg van de schending van de norm waaruit aansprakelijkheid jegens beleggers voortvloeit - zo een dergelijke norm bestaat - die toets niet kan doorstaan.

24. Dit is vaste rechtspraak sinds de uitspraken van 5 maart 1996, gevoegde zaken C-46/93-C-48/93, Jur. 1996, p. I-01029 (Brasserie du Pêcheur en Factortame). 